\title{
Determining the Views of School Principals and Guidance Teachers on Inclusive Practices at Anatolian High-Schools
}

\author{
Tansel Yazicioglu ${ }^{1}$ \\ ${ }^{1}$ The Department of Special Education, Nevsehir Haci Bektas Veli University, Nevsehir, Turkey \\ Correspondence: Tansel Yazicioglu, The Department of Special Education, Nevsehir Haci Bektas Veli University, \\ Nevsehir, 2000 Evler Mah. Damat Ibrahim Pasa Kampusu E Blok, Nevsehir, Turkey. E-mail: \\ tanselyazicioglu@gmail.com
}

Received: October 6, 2019

Accepted: November 11, 2019 Online Published: January 6, 2020

doi:10.5539/jel.v9n1p87

URL: https://doi.org/10.5539/jel.v9n1p87

\begin{abstract}
The number of students who attend an inclusive school in Turkey has been increasing. This increase in the number of students attending inclusive education makes the inclusive policies more significant and requires that schools of all types and levels should be ready for inclusive practices. This study aims at uncovering the views of school administrators and guidance teachers working at Anatolian high schools concerning the inclusive education. The data of the study were collected through focus group interviews. The study was carried out in Ankara during the school year of 2018-2019 with a sample of school administrators and guidance teachers working at different Anatolian high schools. The findings of the study indicate that there are serious problems in inclusive education practices at Anatolian high schools, the educational setting needed for students with special education needs cannot be provided and teachers do not have necessary experience in inclusive education.
\end{abstract}

Keywords: appropriate educational environment, teamwork, negative attitudes, curriculum

\section{Introduction}

Inclusive is defined as a special education plan developed for those students with special education needs and those with some inability (Lindsay, 2007). Inclusive refers to the placement of such students to the classrooms alongside their peers with no special education needs following a delibarate planning and evaluation of the academical and social programs (Lewis \& Doorlag, 1999). Although the focus is on the students with special education needs, inclusive is designed to meet the needs of all students (Ferguson, 1996). The ultimate goals of inclusive include as follows: making all students aware of the differences they have and respectful to one another (Salend, 1998), improving their social understanding and tolerance (Buysse \& Donald, 1993) as well as academical needs of the students with special education needs (Soodak \& Mc Carthy, 2006).

The number of students who attend an inclusive school in Turkey has been increasing. The official data by the Ministry of National Education (MONE) indicate that the total number of students attending an inclusive primary, secondary or high school is 173,117 during the school year of 2013-2014. Of them 152,485 was attending either a primary school or a secondary school. The number of the students with special education needs is 20,632 at high schools (MONE, 2015). Based on the MONE's 2017-2018 school year data it is seen that 257,770 students were attending inclusive schools. Of them, 2,601 students attended pre-service education institutions, 105,098 primary schools, 108,753 secondary schools and 41,318 high schools (MONE, 2018). In the report for the school year of 2018-2019 the following figures are given: 1,260 students attended pre-service education institutions, 115,556 primary schools, 130,624 secondary schools and 48,257 high schools and the total number of students attending inclusive is 295,697 (MONE, 2019). Such an increase in the number of students attending inclusive makes the related policies significant and requires all educational institutions to provide mainstreamed education. On the other hand, Turkey accepted a law no. 6287 on 30 March 2012 and began to implement an educational system which is called 4+4+4 system from 2012-2013 school year. This system made eight-year compulsory education twelve-year. Therefore, students with special education needs who graduated from basic education should attend high schools, and as mentioned above, this change requires all educational institutions to provide inclusive education. In Turkey secondary education institutions include science high schools, social sciences high schools, Anatolian high schools, fine arts high schools, sports high schools, Anatolian imam hatip high schools, imam hatip high schools, vocational and technical Anatolian high schools, vocational and technical 
education centers, multi-program Anatolian high schools, special education vocational high schools and vocational training centers and campuses (MONE, 2019). Students are placed to these institutions through central placement examinations or local placement. Through central placement examinations students are placed to the following schools: anadolu technical program of science high schools, social sciences high schools, educational institutions implementing projects and vocational and technical anatolian high schools. In the local placement several criteria such as the type of schools, the quota of the schools, the secondary education registration area established by the location of the schools and the residence addresses of the students, the presence of the students in the secondary schools, preference priority, school achievement scores, attendance-absenteeism of students and student age are considered (MONE, 2018).

In order to achieve succesful inclusive practices in accordance with their purpose, some preliminary preparations, arrangements, adaptations should be made, and general principles must be fulfilled as well as basic criteria must be met (Kargin, 2004). Such criteria include the organization of physical conditions and adaptation of education environment, provision of supportive special education services, preparation and implementation of individual education programs (Allen \& Cowdery, 2015; Lewis \& Doorlag, 2011). In addition, school administrators, teachers and other staff working at schools, students with and without special needs and their parents all affect the success of inclusive (Aral \& Gürsoy, 2007; Batu \& Kırcaali-İftar, 2011; Kargın, 2004; MONE, 2010; Odluyurt \& Batu, 2012). It is reported that the attitude of school principals plays an important role in this regard and is one of the most effective variables in successful inclusive (Collins \& White, 2001; Jordan, Schwartz, \& McGhie-Richmond, 2009; Lapointe, Poirel, \& Brassard, 2013). It is also reported that school administrators should have information about school's progress in terms of the goals set (Aydin, 1994) and should function as the one who improve the school environment and manage the interaction between school and immediate environment (Basaran, 2000). Therefore, it can be argued that school principals are an important building block for the successful implementation of inclusive practices and meeting the educational needs of all students.

Another decisive factor for successful inclusive is teachers (Aral \& Gürsoy, 2007; Batu \& Kurcaali-İftar, 2011; Kargin, 2004; MONE, 2010; Odluyurt \& Batu, 2012). In particular, guidance teachers have important roles and responsibilities in this regard. These roles and responsibilities are specified in Article 34 of the Regulation on Guidance Services of the Ministry of National Education (2017). The article mentioned above states guidance teachers "take part in the guidance of the development team formed for the individualized education programs (IEPs) to meet the educational needs of students with special education needs, cooperate with related persons, institutions and organizations in the execution of educational services developed for students with special needs and their families, monitor the development of students with special education needs in the support training room and guide the other teachers on this issue and visit students who should be educated at home and in the hospital to provide guidance." Therefore, guidance teachers assume very important responsibilities during all processes in the inclusive education activities.

There are studies on the views of the school administrators about inclusive (Avissar, Reither, \& Leyser, 2003; Bailey \& Plessis, 1997; Balo, 2009; Barnett \& Monda Amaya, 1998; Graham \& Spandagau, 2011; Jahnukainen, 2015; Mattson \& Hansen, 2009; Ramirez, 2006; Salisbury, 2006; Uysal, 1995; Uzun, 200; Valeo, 2008; Yıkılmış \& Sazak Pınar, 2005; Yılmaz Bolat \& Ata, 2017) and of the guidance teachers about the same topic (Akalın, 2014; Aliyev, Erguner Tekinalp, Ulker, \& Shine-Edizer, 2012; Alver, Bozgeyikli, \& Işıklar, 2011; Batu, Kırcaali-İftar, \& Uzuner, 2000; Güven \& Balat, 2006; Özengi, 2009; Yüksel, Diken, Aksoy, \& Karaaslan, 2012). Most of these studies attempted to reveal the views of school administrators working at primary and secondary schools and guidance teachers working at pre-school education institutions and basic education schools regarding inclusive education (Akalın, 2014; Güven \& Balat, 2006; Özengi, 2009). In only one study (Batu, Kurcaali-İftar, \& Uzuner, 2000) the views of the teachers working at a girls' vocational high school where there are students with special education needs. The sample of the study included the teachers and two guidance teachers. Some other studies deal with self-efficacy perception of guidance teachers about psychological guidance and counselling in special education (Yüksel, Diken, Aksoy, \& Karaaslan, 2012), and others analysed the pre-service guidance teachers' attitudes towards inclusive (Alver, Bozgeyikli, \& Işıklar, 2011). The study bu Aliyev, Erguner Tekinalp, Ulker and Shine-Edizer (2012) revealed the views of the pre-school psychological guidance teachers and school administrators about guidance and psychological counselling services. However, no study in Turkey is found on the views of the school administrators and guidance teachers working at Anatolian high schools about inclusive activities. As mentioned above from the school year of 2012-2013 an educational system entitled $4+4+4$ began to be implemented which increased the number of the students with special education needs attending secondary education institutions and therefore, inclusive has become much frequent. For this reason, it is considered that it is important to evaluate the inclusive practices in secondary 
education institutions by school principals and guidance teachers and to determine the current situation. Starting from this idea in this research the views of guidance teachers and school principals about the guidance services related to inclusive practices carried out in the Anatolian high schools were analysed and identified.

\section{Method}

This section includes information on the design of the study, participants, data collection tools, data collection procedure and data analysis.

\subsection{Research Design}

This study aims at uncovering the views of school administrators and guidance teachers working at Anatolian high schools concerning the mainstreamed education. The study was designed around focus group interviews which are part of qualitative research methods. The focus group interview is a data collection technique in which a group of people is brought together by the researcher to express their views and argue about the problem in question (Powell, Single, \& Lloyd, 1996). In other words, the focus groups are formed to allow certain group of people to discuss what they think and feel about a topic, a product or a service. The participants of a focus group should have a common background, and the number of focus groups is generally between six and eight (Krueger \& Casey, 2000).

\subsection{Study Group}

The participants of the study are school principals and guidance teachers working at Anatolian high schools. In qualitative research, different sampling methods can be used to identify the participants. In this study the participants were identified using the criterion sampling which is part of purposive sampling. Marshall and Rossman (2014) defined criterion sampling as the selection of participants based on the pre-established criteria. The criteria are developed by the researchers or they may adopt the previous ones. The criteria employed in the study are as follows: guidance teachers and school principals should work at Anatolian high schools where there are mainstreamed students educated; they should have teaching experience at basic education schools; they should be volunteer to participate in the study; they should be volunteer to record their statements and they should be accessible. A list of Anatolian high schools in which students with special education needs are educated was taken from Ankara National Education Directorate. From this list eight Anatolian high schools were randomly selected. Of these schools there were ten students with special education needs. More specifically, in five schools there were three students with special education needs, in two schools there were four students with special education needs and in one school there were three students with special education needs. Then these schools were visited, and the guidance teachers and school principals were informed about the study. They all volunteered to take part in the study. School administrators were coded as A1, A2, A3, etc. and the guidance teachers as G1, G2, G3, etc. Table 1 and Table 2 show the demographical data on the school administrators and guidance teachers participated in the study, respectively.

Table 1. Demographical data on the school administrators participated in the study

\begin{tabular}{llll}
\hline School administrators & Gender & Age & Professional experience (Years) \\
\hline A1 & Male & 51 and older & 31 and more \\
A2 & Male & $41-50$ & $21-30$ \\
A3 & Male & 51 and older & 31 and more \\
A4 & Male & 51 and older & $21-30$ \\
A5 & Male & $41-50$ & $11-20$ \\
A6 & Male & 51 and older & $11-20$ \\
A7 & Male & 51 and older & $21-30$ \\
A8 & Male & 51 and older & $21-30$ \\
\hline
\end{tabular}

As can be seen in Table 1 all school administrators are male. Of them two are in the age group of 41-50, and six are 51 or older. Concerning the professional experience two have a teaching experience of 31-40 years, four 2130 years and two 11-20 years. 
Table 2. Demographical data on the guidance teachers participated in the study

\begin{tabular}{llll}
\hline Guidance Teacher & Gender & Age & Experience (Years) \\
\hline G1 & Female & $41-50$ & $21-30$ \\
G2 & Female & $31-40$ & $11-20$ \\
G3 & Female & $31-40$ & $11-20$ \\
G4 & Female & 51 and older & 31 and more \\
G5 & Female & $41-50$ & $21-30$ \\
G6 & Female & $41-50$ & $11-20$ \\
G7 & Female & $31-40$ & $11-20$ \\
G8 & Female & $41-50$ & $21-30$ \\
\hline
\end{tabular}

Table 2 shows that all of the guidance teachers sampled are female. There are four guidance teachers aged between $41-50$, three between $31-40$ and one guidance teacher sampled is aged more than 51 . Concerning experience of teaching three of them have an experience of 21-30 years, four 11-20 years and one has an experience of 31 years or more.

\subsection{Data Collection Tools}

The data of the study were collected through the items asked to the participants in focus group interviews. More specifically, these items are about their views concerning the inclusive carried out at high schools. The interview items were reviewed by two special education experts, and no modification was needed based on their feedback. In the focus groups the following items were asked to the participants: (1) What do you think about inclusive education practice? (2) What do you think about inclusive education practice at the school where you work? (3) What are the differences between inclusive in basic education schools and inclusive in high schools? and (4) What are your suggestions to have a successful inclusive practice?

These items were first employed in a pilot study involving two school administrators and guidance teachers working at an inclusive school. Following the pilot study, the participants provided feedback about the interview items.

\subsection{Data Collection and Analysis}

The study was carried out in Ankara during the school year of 2018-2019. The focus group interviews with the school administrators was carried out on 13 May 2019 and that with the guidance teachers on 24 May 2019. The focus group interviews were held in a secondary school which was easy to access. The participants were informed about the date and place of the focus group interviews through telephone calls. In addition, e-mail messages were sent to them including information on the date and place of the focus group interviews. The date and hour of the interviews were selected based on the participants' working hours. The focus group meeting was held around the oval table of size and width, which could accommodate 10 people in the meeting room of the school where some of the participants were working. Paper, pen and water were available for each participant at the table. The interviews were conducted in a comfortable environment by the author and a faculty member working in the special education department of a university who functioned as an observer. The moderator was a faculty member who also worked as a teacher and school administrators at public schools affiliated to the Ministry of National Education for many years and is currently working on the inclusive of educational practices in a special education department at a university. Focus group interviews were recorded by the school technician using a video device. In addition, some notes were kept by the author during the interview process. The interviews with the school administrators lasted for eighty-six minutes, and those with the guidance teachers lasted for eighty minutes. The interview items were asked to the participants in the order given in the interview form, and the answers of the participants were recorded. A total of seventy-six pages of data was obtained from the focus group interviews.

\subsection{Data Analysis}

The data collected were analysed using the content analysis technique. Content analysis is a systematic data collection analysis technique in which words or phrases in a text are summarized with fewer content categories and coded rules. In this technique, it is aimed to obtain concepts and relationships that can explain the data (Büyüköztürk, Kılıç-Çakmak, Akgün, Karadeniz, \& Demirel, 2014).

The vieo recordings of the interviews were transcribed by the author. In addition, the notes taken during the interviews were. Then the author and a faculty member working in the special education department at a university independently analyzed the written texts generated from the interviews. Next the data were divided 
into components to make sense in themselves and each component was coded. Finally, for each code a conceptual meaning was identified and these codes were used to develop some themes. The concepts developed through the analyses by the author and the faculty member were compared. The concepts were grouped as similar concepts and different concepts. Then the ratio of common concepts to the whole concept list was calculated. It is found that the interraters' mutual agreement is $89 \%$.

\section{Results}

The findings of the showed that the themes developed are categorized under four headings with several sub-headings. These are discussed as follows:

\subsection{Opinions on Inclusive Education Practices}

The views of the participants about the inclusive education are given in Table 3 and Table 4 .

Table 3. Views of the school administrators about inclusive

\begin{tabular}{lll}
\hline Sub-themes & Views & Codes \\
\hline Legal requirements & The law requires that these should should be offered inclusive. & A1 \\
& We have to accept these students in inclusive education. It is their right. & A4, A5 \\
& We have a legal requirement. & \\
Applicability & Problems in practice. & A1, \\
& Practices are not so perfect. & A3, \\
& We implement inclusive partly. & A4, A6 \\
& There is no full implementation of inclusive. & A8 \\
Utilitarianism & Not so beneficial. & A2 \\
& I think it is beneficial. But necessary conditions should exist at schools. & A7 \\
\hline
\end{tabular}

Table 3 indicates that there are five school principals who argued that inclusive can be implemented. There are three school principals who emphasized the fact that inclusive is a legal requirement and there are two school principled who adopted a utilitarian approach in regard to the benefits of inclusive. For instance, A1 stated "By law, these kids have to come to high school. We have no chance not to accept them." Another school principle coded A4 argued "I can not say that we can fully implement it. We can partially implement it. Because we're not ready to implement inclusive at schools." Another school principal A2 expressed the following views: "Inclusive education is a very useful practice in my opinion. Students can socialize with their peers. They feel themselves happy and safe. That's why it is very beneficial for them."

Table 4. Views of the guidance teachers about inclusive

\begin{tabular}{lll}
\hline Sub-themes & Views & Codes \\
\hline Socialization & I find it important for the social development of the children. \\
& It is a useful program for them to communicate with their peers. \\
Educational opportunity & It is a significant opportunity for students with special education needs. \\
Attitude and approach of teachers & The perspectives of teachers about mainstreamed students are very important. \\
& The important thing is that teachers accept the child. G2, \\
It is useful if teachers want. & A great program if the necessary conditions can be provided. \\
Proper educational environment & Inclusive education is useful and necessary. \\
Utilitarianism & I think it is useful. & G8 \\
\hline
\end{tabular}

As can be seen in Table 4 two guidance teachers focused on the socialization opportunities of inclusive and the other two on being an opportunity for students with special education needs. On the other hand, three guidiance teachers reported the significance of teachers' attitudes and approaches in inclusive whereas the other three emphasized the significance of educational environment in inclusive. There are three guidance teachers who mentioned the benefits of inclusive. For instance, a guidance teacher, G1, explained her views about inclusive as follows: "I think that inclusive is very important for the social development of students. For me it is the most significant advantage of the inclusive." Another guidance teacher, G6, described it as follows: "Inclusive is very significant opportunity for students with special education needs." The views of a guidance teacher, G8, is as follows: "Teachers are extremely important in this process. Their attitudes towards inclusive should be positive. If teachers want to implement it, it would be successful." The views of another guidance teacher, G2, is given as 
follows: "Inclusive is a great program if the necessary conditions can be provided." A guidance teacher coded G6 expressed her views as follows: "I think it is beneficial to the students. They gain different positive things."

\subsection{Views About Inclusive Educational Activities at Anatolian High Schools}

The views of the school principals and guidance teachers about inclusive educational activities at Anatolian high schools are given in Table 5 and Table 6, respectively.

Table 5. Views of the school principals about inclusive educational activities at Anatolian high schools

\begin{tabular}{lll}
\hline Sub-themes & Views & Codes \\
\hline Proper educational environment & These children need special care in education. & A1, A2, A3 \\
& Physical conditions are not sufficient. & A5, A6, A7 \\
& Class size should be less. & A8 \\
Incompetency of teachers & Some of the teachers are imcompetent for inclusive. & A1, A2, A3, \\
& & A4, A7, A8 \\
Placement & Some students have very serious disability. & A2 \\
& Some students are not suitable for these schools. I think every mainstream & A4, A5 \\
& student should not attend high school. & A7 \\
\hline
\end{tabular}

Table 5 indicates that seven school administrators think that inclusive at Anatolian high schools is not implemented in proper conditions and six school administrators argue that inclusive is not properly implemented and four school administrators state that there are problems about the placement of the students with special education needs. For instance, a school admnistrator coded A8 expressed his views as follows: "If inclusive should be implemented, class size should be less crowded." The school administrators coded A1 and A4 stated "Teachers are incompetent in inclusive. Some of them have not came across a mainstreamed student."

Table 6. Views of the guidance teachers about inclusive educational activities at Anatolian high schools

\begin{tabular}{lll}
\hline Sub-themes & Views & Codes \\
\hline Planning & Individualized education programs (IEPs) are not at the desired level. & G1, G3, \\
& Lack of relevant inclusive plans & G5 \\
& Plans and programs related to inclusive look good only on paper. & G4, G6, G8 \\
Team work & We employ IEPs, but there is no serious team work about them. & G6, G7 \\
& Our teachers do not work in cooperation, unfortunately. & G8 \\
& The IEP process works well at our school. & G2 \\
& Our class schedule does not fit for teamwork. & G1, G6, G5 \\
Parental pressure & Less expectations on the part of parents. & G6 \\
& Parents of students with special needs constantly want their children to be cared for. & G7, G8 \\
Placement & Placement does not take into account the conditions of schools. & G5 \\
& Vocational schools are more suitable for some inclusive students. &
\end{tabular}

Table 6 indicates that six guidance teachers reported that there are some planning problems in inclusive practices at Anatolian high schools and that six guidance teachers stated that team work related to inclusive is not sufficient. There are also four guidance teachers who reported that the parents of the students with special education needs put pressure on teachers to have more time for their children. The problems related to the placement of the students with special education needs were stated by three guidance teachers. For instance, a guidance teacher coded G4 stated "Our teachers develop IEPs, but they mostly get them online. And as a result, plans and programs remain only on paper." Another guidance teacher coded G6 argued "Unfortunately, our course schedules do not fit for teamwork." Another guidance teacher coded G2 told" In our school, the IEP process works well. Our IEP unit and teachers work in harmony." Another guidance teacher coded G5 focused on the parental pressure on teachers and stated "The parents of the mainstreamed students have very high expectations. So sometimes we have trouble." Another guidance teacher coded R7 expressed her views as follows: "The characteristics of the schools where inclusive takes place should be well known. The conditions of schools must be taken into consideration."

\subsection{Differences of Inclusive Education Practices According to School Types}

The views of the school administrators and guidance teachers about the differences concerning the inclusive activities at high schools and at basic education schools are given in Table 7 and Table 8, respectively. 
Table 7. Views of the school administrators about the differences

\begin{tabular}{lll}
\hline Sub-themes & Views & Codes \\
\hline $\begin{array}{l}\text { Attitudes and approach of } \\
\text { classroom teachers }\end{array}$ & $\begin{array}{l}\text { The class teacher may not want the students with special education needs in his } \\
\text { class. But we do not have such a situation at our school. }\end{array}$ & A1, A6, A8, \\
$\begin{array}{lll}\text { Experience of teachers } & \text { Teachers at primary and secondary schools are more experienced. } & \text { A1, A2, A4, A5 } \\
\text { Physical conditions } & \text { Particularly primary schools are more advantageous in terms of physical conditions. } & \text { A2, A3, A7 }\end{array}$ \\
\hline
\end{tabular}

Table 7 indicates that three school administrators reported the differences concerning the inclusive activities at high schools and at basic education schools in terms of teachers' attitudes and four school administrators in terms of teachers' professional experience and three school administrators in terms of physical conditions. For instance, a school administrator, coded A6, stated the following views regarding these differences: "Particularly, in primary schools, classroom teachers may not want students to be integrated in their class. Because he has to take care of these students for four years. However, at high schools, teachers think that they just give courses to these students for three or two hours and that they could manage it somehow. I think there is a difference between the attitudes of teachers working at basic education schools and at high schools. More specifically, class teachers have to take care of everything for the child. High school teachers only give their lessons." Another school administrator coded M1 stated the followings focused on the experience of the teachers: "We used to accept students based on their examination scores. But now our students are those whose homes are near to the school. There were less students with special education needs attending high schools. But now we have seven students with special education needs. Our teachers do not have enough experience in regard to inclusive. But primary and secondary school teachers have been educating students with special education needs for years..." another school principal coded A2 emphasized the differences between basic education schools and high schools in terms of physical conditions and stated "Basic education schools are more appropriate for inclusive in terms of physical conditions. They have more available physical environment. For example, some schools may have places such as drama rooms, support training rooms and empty classrooms. In our case, both the buildings are very large, the number of students is very high, and we are experiencing shortage of space."

Table 8. Views of the guidance teachers about the differences

\begin{tabular}{lll}
\hline Sub-themes & Views & Codes \\
\hline Academical skills & Focus on academical skills of the mainstreamed students. & G3 \\
Class sizes & Class size in primary schools may be 20-25 students. But in high schools it is 35-40 & G4, G7 \\
& students & G1 \\
Peer relations & $\begin{array}{l}\text { I think the inclusive students at high schools are more accepted than their peers. } \\
\text { Educational programs } \\
\text { İnclusive courses at primary and secondary schools may have programs for social skills. } \\
\text { however, at high schools courses focus on academical topics. }\end{array}$ & G2, G5, G6, G8 \\
\hline
\end{tabular}

As can be seen in Table 8 two guidance teachers stated the differences concerning the inclusive activities at high schools and at basic education schools in terms of class size, one guidance teacher in terms of peer relations and four guidance teachers in terms of educational programs. For instance, a guidance teacher, G7, expressed her views about class sizes as follows: "Primary schools are luckier than high schools. Because the number of students in classrooms is less than that in primary schools. In primary schools there can be classes of 20-25 students. In high schools it is generally 35-40 students. This naturally affects the time duration teachers care for the mainstream student." A guidance teacher, R1, argued that at high schools, students with special education needs are much more accepted by their peers. A guidance teacher, R5, stated that the real difference stems from the education programs and expanded her views as follows: "In primary and secondary schools there are education programs supporting social skills of students. At high schools the focus is on lectures. For me it is the important thing ..."

\subsection{Suggestions for Successful Inclusion}

The suggestions by the school administrators and guidance teachers concerning a successful inclusive education are given in Table 9 and Table 10, respectively. 
Table 9. Suggestions by school administrators

\begin{tabular}{llll}
\hline Sub themes. & Quotation & Codes \\
\hline Inclusive culture & The culture should be created in schools about inclusive. & A1 & A5, A7 \\
Qualified IEP & IEPs should be madeproper and realistic. & A2 \\
Social acceptance & These children are our children. & A1, A3, A4, A6, A7, A8 \\
In-service training & Managers and teachers should be trained in special education & 6 \\
\hline
\end{tabular}

As can be seen in Table 9 on school principal suggested that there should be a school culture about inclusive. Two school principals suggested to have quality IEPs. One school principal suggested that students with special education needs should be accepted by the school personnel. There are six school principals who suggested that in-service training activities should be organized concerning inclusive. For instance, a school principal coded A8 expressed the followings: "If we want a successful inclusive, first of all, the knowledge and experience of the teachers about it should be increased. All administrators and teachers, especially school principals, should be given in-service training concerning special education."

Table 10. Suggestions by guidance teachers

\begin{tabular}{lll}
\hline Sub-themes & Suggestions & Codes \\
\hline Efficient management approach & School administrators should attach importance to inclusive. & G2, \\
& School administration has significant roles to play in inclusive. & G5 \\
& Full participation in meetings. & G6 \\
& Monthly evaluative meetings. & G1, G7, G8 \\
& Cooperation with speacial education teachers and rehabilitation teachers & G4 \\
& Cooperation with parents. & G5 \\
Parental support & Emotional and social support to parents. & G3 \\
& Visits to parents & G3, G8 \\
Proper support and training & Individual work should be increased. & G2, G4, G7, G8 \\
Applicable BEP & IEPs should be done in a useful way, not as a showpiece. & G1, G3, G4, G6 \\
\hline
\end{tabular}

As can be seen in Table 10 two guidance teachers suggested that there should be an effective management approach towards inclusive. There are five guidance teachers who suggested team work and four guidance teachers who suggested parental support. The number of the guidance teachers who suggested proper assisted education is four. The same number of guidance teachers suggested feasible IEPs. For instance, a guidance teacher who suggested tem work, coded 6, expressed her views as follows: "You know we have IEP units. The team working at this unit makes significant decisions. Full participation in meetings should be provided if we want a proper inclusive implementation."

\section{Discussion}

When the opinions of school principals and guidance teachers working at Anatolian mainstreamed high schools regarding inclusive education practices are evaluated, it is understood that they percieve such education practices as a legal requirement and that for school principals, inclusive education is not a useful practice due to the problems faced. However, guidance teachers reported that it is very useful despite the problems experienced during the process. School principals may not find inclusive beneficial due to problems. On the other hand, research suggests that the attitutdes of school principals towards inclusive are very significant variables in successful inclusive practices (Collins \& White, 2001; Jordan, Schwartz, \& McGhie-Richmond, 2009; Lapointe, Poirel, \& Brassard, 2013). It is also stated that school administrators are obliged to know the progress of the school in terms of objectives established (Aydin, 1994) and that they are the individuals who will improve the environment of the school and manage the interaction of the school with the environment (Başaran, 2000). The guidance teachers participated in the study suggested an effective school administration to have successful inclusive at schools. Although the guidance teachers stated that they found the educational practices beneficial through inclusive, they emphasized the necessity of creating appropriate educational environments in inclusive education and pointed out that the attitudes and approaches of the teachers are very important in this regard.

Considering the participants' views on inclusive education in Anatolian high schools, it is seen that there are serious problems in the process of inclusive. Basic problems stated by the participants include insufficient physical conditions of schools, crowded class size, improper implementation of IEPs and team woek. This finding suggests that inclusive implemented at Anatolian high schools is not given properly. It is not desirable 
that IEPs, which are an important plan in meeting the educational needs of students with special needs, cannot be operated in a proper way and that only one of the guidance teachers stated that IEP works well in their schools. On the other hand, research suggests that criteria such as organization of physical conditions at schools and adaptation of the educational environment for the mainstreamed students and the preparation and implementation of individual training programs affect the success of inclusive education practices (Allen \& Cowdery, 2015; Lewis \& Doorlag, 2011).

When the opinions of the participants regarding the differences between inclusive at high schools and inclusive at primary and secondary schools are considered, it is concluded that there are some differences between these educational practices. In particular, it is stated by the school principals that the teachers working at the Anatolian high schools are less inexperienced than the teachers working at the basic education schools in regard to inclusive which clearly suggests that the knowledge and experience of the teachers working at these schools should be improved. The school principals also stated that there are differences between the attitudes and approaches of classroom teachers working at primary schools and the attitudes and approaches of teachers working at high schools in regard to students with special education needs. The school principles reported that classroom teachers at primary or secondary schools may not want students with special education needs in the classes. High schools teachers do not exhibit negative attitudes due to the fact that they spend less time students with special education needs. This situation is pleasing in terms of the acceptance of the students with special needs by teachers working at secondary education institutions. However, apart from social acceptance, processes such as individualized education, support education services and guidance should also be taken into consideration by teachers. In numerous studies it is stated that teachers are one of the factors affecting the success of educational practices through inclusive (Aral \& Gürsoy, 2007; Batu \& Kırcaali-İftar, 2011; Kargın, 2004; MONE 2010; Odluyurt \& Batu, 2012).

One of the differences regarding the inclusive at primary and secondary schools and high schools reported by the guidance teachers is the content of educational programs. As reported by the guidance teachers there are educational programs at primary and secondary schools which support social skills of the students that are not emphasized at high schools. This may cause teachers and students at high schools to focus more on academic skills and limit the improvement of their social skills. Therefore, it may prevent from fulfilling the potential of inclusive. For instance, one of the guidance teachers stated that at the Anatolian high schools more academic skills were emphasized in courses.

Another finding of the study regarding the differences between inclusive at high schools and inclusive and primary and secondary schools is the physical conditions of schools. This finding of the study reveals that Anatolian high schools have more disadvantageous physical conditions than basic education schools. Thus, both school principals and guidance teachers emphasized that the classes are more crowded than those at basic education schools. This situation is a negative condition in terms of meeting the educational needs of the students attending inclusive education. For instance, Kircaali-Iftar (1998) argued that one of the most important factors which improve the success of inclusive education is the appropriate physical conditions of the school or classroom.

When the suggestions of the participants are evaluated, it is seen that in-service training activities should be increased and teamwork should be given importance in schools. In this regard, the inclusive teacher training project initiated in cooperation with the Ministry of National Education and United Nations International Children's Emergency Fund (UNICEF) is considered to be important. Inclusive Teacher Training aims to strengthen the capacity of educational staff providing services to all children, particularly disadvantaged children (children in need of special education, refugee children under temporary protection, children who have been exposed to violence, etc.) and to ensure that each child has access to quality inclusive education. In this project, ten modules were developed to contribute to the professional development of teachers. These modules include introduction to inclusive education, inclusive teaching and assessment, inclusive learning environments (physical and psycho-social), school-family and community cooperation, working with children with disabilities, teaching Turkish as a second language, working with children who are exposed to violence, working with children affected by migration and terrorism, working with children affected by natural disasters. Apart from these, it is seen that there are some suggestions such as the implementation of feasible and quality IEPs, providing family support and increasing individualized education. The suggestions of school principals and guidance teachers are thought to be important in terms of inclusive practices implemented at Anatolian high schools. It is thought that it would be beneficial to inform high school teachers about special education and inclusive practices. In particular, the functioning of the IEP unit and team work in schools should be made functional and cooperation should be improved. It is thought that taking into account the number of students in inclusive classes by school 
administrations and performing activities and programs that improve social skills of the students with special education needs will increase the success in inclusive practices. Inclusive practices implemented at Anatolian high schools should be reviewed by the Ministry of National Education and the problems in practice should be eliminated by the ministerial bodies. Although this study is limited to eight Anatolian high schools, it is thought that it will shed light on future research. Future studies may be conducted in different provinces with more numbers of participants. The opinions of the other teachers rather than school principals and guidance teachers, families and even students about the inclusive practices implemented at Anatolian high schools can be analysed.

\section{Acknowledgments}

Any grants or other financial support was not received for my study. I assert that written informed consent was taken from participants for reporting the results. The manuscript is original work of author. I confirm that this manuscript has not been published elsewhere nor is it currently under consideration for publication in any other journal.

\section{References}

Aliyev, R., Erguner-Tekinalp, B., Ulker, R., \&Shine-Edizer, F. (2012). The perceptions of school counselors and principals towards new psychological counseling and guidance services in early childhood education in Turkey. Educational Sciences: Theory and Practice, 12(4), 3083-3098.

Allen, K. E., \& Cowdery, G. E. (2015). The exceptional child: Inclusion in early childhood education (8th ed.). Stamford, CT: Cencage Learning.

Alver, B., Bozgeyikli., H., \& Işıklar, A. (2011). Psikolojik danışma ve rehberlik programı öğrencilerinin kaynaştırma eğitimine yönelik tutumlarının incelenmesi. Atatürk Üniversitesi Sosyal Bilimler Enstitüsü Dergisi, 15(1), 155-168.

Akalın, S. (2014). Okul öncesi eğitim kurumlarında çalışan rehber öğretmenlerin kaynaştırma uygulamalarına ilişkin gereksinimleri. International Journal of Early Childhood Special Education, 6, 1.

Aral, N., \& Gürsoy, F. (2007). Özel eğitim gerektiren çocuklar ve özel eğitime giriş. İstanbul: Morpa Kültür Press.

Avissar, G., Reiter, S., \& Leyser, Y. (2003). Principals' views and practices regarding inclusion: the case of Israelielementary school principals. European Journal of Special Needs Education, 18(3), 355-369. https://doi.org/10.1080/0885625032000120233

Aydın, M. (1994). Eğitim yönetimi. Ankara: Hatiboğlu Press.

Balo, E. D. (2015). İlkokullarda kaynaştırma eğitimi uygulamalarında karşılaşılan sorunlar ve çözüm önerileri. Unpublished master's thesis, Firat University, Elazığ.

Barnett, C., \& Monda-Amaya, L. E. (1998). Principals' knowledge of and attitudes toward inclusion. Remedial and Special Education, 19(3), 181-192. https://doi.org/10.1177/074193259801900306

Basaran, İ. E. (2000). Ĕ̈itim yönetimi. Ankara: Feryal Press.

Batu, S., Iftar, G. K., \& Uzuner, Y. (2000). Özel gereksinimli öğrencilerin kaynaştırıldığı bir kız meslek lisesindeki öğretmenlerin kaynaştırmaya ilişkin görüş ve önerileri. Ankara Universitesi Eğitim Bilimleri Fakültesi Özel Ĕ̈itim Dergisi, 5(02).

Batu, S., \& Kırcaali-İftar, G. (2011). Kaynaştırma (6th ed.). Ankara: Kök Press.

Buysse, V., \& Donald, B. B. (1993). Behavioral and developmentaloutcomes in young children withdisabilities in integrated and segregated settings: A review of comparative studies. Journal of Special Education, 26(4), 434-462. https://doi.org/10.1177/002246699302600407

Büyüköztürk, Ş., Kılıç, Ç. E., Akgün, Ö. E., Karadeniz, Ş., \& Demirel, F. (2014). Bilimsel araştırma yöntemleri (17th ed.). Ankara: Pegem Akademi Press.

Collins, L., \& White, G. P. (2001). Leading inclusive programs for all special education students: A pre-service training program for principals. Retrieved from https://eric.ed.gov/?id=ED456604

Ferguson, D. L. (1996). İs it inclusion yet? Bursting the bubbles. In M. S. Berres, D. L. Ferguson, P. Knoblock \& C. Woods (Eds), increating tomorrow's schools today: Stories of inclusion, change and renewal (pp. 16-37). New York: Teachers College Press.

Graham, L. J., \& Spandagou, I. (2011). From vision to reality: Views of primary school principals on inclusive education in New South Wales, Australia. Disability \& Society, 26(2), 223-237. 
https://doi.org/10.1080/09687599.2011.544062

Güven, Y., \& Balat, G. (2006). Kaynaştırma uygulamalarına ilişkin rehber öğretmenler ve rehberlik araştırma merkezi çalışanlarının görüşleri. M.Ü. Atatürk Eğitim Fakültesi eğitim Bilimleri Dergisi, 24, 95-108.

Jahnukainen, M. (2015). Inclusion, integration, or what? A comparative study of the school principals' perceptions of inclusive and special education in Finland and in Alberta, Canada. Disability \& Society, 30(1), 59-72. https://doi.org/10.1080/09687599.2014.982788

Jordan, A., Schwartz, E., \& McGhie-Richmond, D. (2009). Preparingteachers for inclusive classrooms. Teaching and Teacher Education, 25(4), 535-542. https://doi.org/10.1016/j.tate.2009.02.010

Kargın, T. (2004). Kaynaştırma: tanımı, gelişimi ve ilkeleri. Ankara Üniversitesi Ĕ̌itim Bilimleri Fakültesi Özel Ĕgitim Dergisi, 5(2), 1-13. https://doi.org/10.1501/Ozlegt_0000000080

Kırcaali-İftar, G. (1998). Kaynaştırma ve destek özel eğitim hizmetleri. In S. Eripek (Ed.), Özel eğitim (pp. 1725). Eskişehir: Anadolu Üniversitesi Açık Öğretim Fakültesi Yayınları.

Krueger, R. A., \&Casey, M. A. (2000). Focusgroups: A practicalguide for applied research. ThousandOaks, CA: Sage.

Lapointe, P., Poirel, E., \& Brassard, A. (2013). Beliefs and responsibilities of educational stakeholdersconcerning student success and effective principal leadership. Canadian Journal of Educational Administration and Policy, 142 .

Lewis, R. B., \& Doorlag, D. H. (1999). Teaching special education students in general education classrooms. New York: Merril, Prentice Hall.

Lewis, R. B., \& Doorlag, D. H. (2011). Teaching students with special needs in general education classrooms (8th ed.). Upper Saddle River, NJ: Pearson.

Lindsay, G. (2007). Educational psychology and the effectiveness of inclusive education/mainstreaming. British Journal of Educational Psychology, 77(1), 1-24. https://doi.org/10.1348/000709906X156881

Marshall, M. N., \& Rossman, G. B. (2014). Designing qualitative research. New York: Sage.

Mattson, E. H., \& Hansen, A. M. (2009). Inclusive and exclusive education in Sweden: principals' opinions and experiences. European Journal of Special Needs Education, 24(4), 465-472. https://doi.org/10.1080/08856250903223112

Ministry of National Education. (2010). İlköğretim okullarındaki kaynaştırma uygulamalarının değerlendirilmesi. Ankara: Milli Eğitim Press.

Ministry of National Education. (2015). Milli eğitim istatistikleri örgün eğitim 2014-2015. Retrieved from https://sgb.meb.gov.tr/www/mill-egitim-istatistikleri-orgun-egitim-2014-2015/icerik/153.pdf

Ministry of National Education. (2017). Rehberlik hizmetleri yönetmeliği. Retrieved from http://orgm.meb.gov.tr/meb_iys_dosyalar/2017_11/10113305_yeni_rehbrlk_yon.pdf

Ministry of National Education. (2018). Millieğitim istatistikleri örgün eğitim 2017-2018. Retrieved from http://sgb.meb.gov.tr/meb_iys_dosyalar/2018_09/06123056_meb_istatistikleri_orgun_egitim_2017_2018.p df

Ministry of National Education. (2019). Milli eğitim istatistikleri örgün eğitim 2017-2018. Retrieved from http://sgb.meb.gov.tr/meb_iys_dosyalar/2018_09/06123056_meb_istatistikleri_orgun_egitim_2017_2018.p df

Odluyurt, S., \& Batu, S. (2013). Kaynaştırmanın başarısını etkileyen faktörler. In S. Batu, A. Çolak \& S. Odluyurt (Eds), in Özel Gereksinimli Çocukların Kaynaştırllması (pp. 25-37). Ankara: Vize Press.

Özengi, S. (2009). Eskişehir ilinde kaynaştırma uygulamalarının yürütüldüğü ilköğretim okullarındaki rehber ögretmenlerin kaynaştırmaya ilişkin görüşleri. Unpublished master's thesis. Anadolu University, Eskişehir.

Powell, R. A., Single, H. M., \& Lloyd, K. R. (1996). Focusgroups in mentalhealth research: Enhancing the validity of user and providerquestionnaires. International Journal of Social Psychology, 42(3), 193-206. https://doi.org/10.1177/002076409604200303

Salisbury, C. L. (2006). Principals' perspectives on inclusive elementary schools. Research and Practice for Persons with Severe Disabilities, 31(1), 70-82. https://doi.org/10.2511/rpsd.31.1.70

Soodak, L. C., \& McCarthy, M. R. (2006). Classroom management in inclusive settings. In C. M. Evertson \& C. 
S. Weinstein (Eds.), Handbook of classroom management: Research, practice and contemporary issues (pp. 3-15). Lawrence ErlbaumAssociates, Inc. ERIC Number: ED493767

Ugwu, C. J., \& Jonathan, N. O. (2018). Investigation of principals' attitude towards inclusion of special needs students in public and private secondary schools in rivers state, Nigeria. American Journal of Applied Psychology, 6(1), 1-7. https://doi.org/10.12691/ajap-6-1-1

Uysal, A. (1995). Öğretmen ve okul yöneticilerinin zihin engelli çocukların kaynaştırılmasında karşılaşılan sorunlara ilişkin görüşleri. Unpublished master's thesis. Anadolu University, Eskişehir.

Uzun, G. (2009). Kaynaştırma uygulamalarında ilköğretim okulu müdürlerinin rolü ve kaynaştırma uygulamalarına ilişkin görüş ve önerileri. Unpublished master's thesis. Maltepe University, İstanbul.

Valeo, A. (2008). Inclusive Education supportsystems: Teacher and administrator views. International Journal of Special Education, 23(2), 8-16.

Yıkılmış, A., \& Sazak, P. E. (2005). İlköğretim okulu müdürlerinin kaynaştırmaya yönelik görüşlerinin belirlenmesi. Abant İzzet Baysal Eğitim Fakültesi Dergisi, 5, 1.

Yılmaz-Bolat, E., \& Ata, N. (2017). Kaynaştırma uygulamaları hakkında okul yöneticilerinin görüşleri. Sosyal Bilimler Dergisi, 7-14. https://doi.org/10.31834/kilissbd.358406

Yüksel, K., Diken, İ., Aksoy, V., \& Karaaslan, Ö. (2012). Rehber öğretmen adaylarının özel eğitimde psikolojik danışma ve rehberliğe iliş-kin öz-yeterlik algıları, Pamukkale Üniversitesi Eğitim Fakültesi Dergisi, 31(I), $137-148$.

\section{Copyrights}

Copyright for this article is retained by the author, with first publication rights granted to the journal.

This is an open-access article distributed under the terms and conditions of the Creative Commons Attribution license (http://creativecommons.org/licenses/by/4.0/). 